\title{
LOW BIRTHWEIGHT AND ITS BIOPSYCHOSOCIAL AND ECONOMIC DETERMINANTS: A NEW EVIDENCE USING A PATH ANALYSIS MODEL FROM JAMBI, SOUTH SUMATERA
}

\author{
Iga Trisnawati'), Harsono Salimo²), Bhisma Murti1) \\ 1)Masters Program in Public Health, Universitas Sebelas Maret \\ 2)Department of Pediatrics, Dr. Moewardi Hospital, Surakarta
}

\begin{abstract}
Background: Low birth weight (LBW) is a major maternal and child health problem, especially in developing countries. Children who are born with weight less than $2.5 \mathrm{~kg}$ are vulnerable for infections, malnutrition, psychological disorder, and decreased the intelligence, and dying, in their early childhood. Little is known about the association between LBW and the biopsychosocial and economic factors in Indonesia. This study aimed to determine the biopsychosocial and economic determinants of LBW in Jambi, South Sumatera.

Subjects and Method: This was a case control study carried out at 20 community health centers in Jambi, South Sumatera, from December 2017 to January 2018. A total sample of 200 newborn infants consisting of $50 \mathrm{LBW}$ and 150 normal birthweight newborn infants were selected for this study by fixed disease sampling. The dependent variable was birthweight. The independent variables were maternal age, maternal mid-upper arm circumference (MUAC), gestational age, infant sex, maternal gestational stress, maternal education, family income at gestational period, and sanitation. Data on birthweight and MUAC were taken from obstetric record. The other data were collected by questionnaire. The data were analyzed by path analysis.

Results: The risk of LBW was increased by female sex $(b=0.99 ; 95 \% \mathrm{CI}=-0.12$ to $2.12 ; \mathrm{p}=0.081)$, and high maternal stress $(b=2.35 ; 95 \% \mathrm{CI}=0.70$ to $4.01 ; \mathrm{p}=$ 0.005). The risk of LBW decreased with gestational age $\geq 37$ weeks $(b=-5.06$; $95 \% \mathrm{CI}=-6.49$ to $-3.62 ; \mathrm{p}=0.000)$, and good sanitation $(\mathrm{b}=-1.04 ; 95 \% \mathrm{CI}=-2.13$ to $0.05 ; \mathrm{p}=0.062)$. Gestational age increased with nutritional status $(\mathrm{b}=1.91$; $95 \% \mathrm{CI}=0.94$ to $2.89 ; \mathrm{p}<0.001)$, and family income $(\mathrm{b}=1.50 ; 95 \% \mathrm{CI}=0.66$ to 2.32; $\mathrm{p}=0.000)$. Nutritional status increased with family income $(\mathrm{b}=1.45 ; 95 \%$ $\mathrm{CI}=0.55$ to $2.33 ; \mathrm{p}=0.001)$. Sanitation increased with family income $(\mathrm{b}=0.71$; $95 \% \mathrm{CI}=0.01$ to $1.41 ; \mathrm{p}=0.046)$. Family income increased with education $(\mathrm{b}=$ 1.37; $95 \% \mathrm{CI}=0.57$ to $2.18 ; \mathrm{p}=0.001)$. Education increased with maternal age ( $\mathrm{b}=$ $1.03 ; 95 \% \mathrm{CI}=0.19$ to $1.87 ; \mathrm{p}=0.015)$. Maternal stress decreased with family income $(b=-1.34 ; 95 \% \mathrm{CI}=-2.50$ to $-0.19 ; \mathrm{p}=0.022)$.

Conclusion: The risk of LBW increased with gestational age $<37$ weeks, female sex, high maternal stress, and poor sanitation. LBW is indirectly affected by maternal age, nutritional status, maternal education and family income.
\end{abstract}

Keywords: biopsychosocial, economic, determinant, LBW, Jambi.

\section{Correspondence:}

Iga Trisnawati. Masters Program in Public Health, Universitas Sebelas Maret, Surakarta, Jl. Ir. Sutami No. 36 A, 57126, Surakarta, Central Java.

Email: trisnawatiiga27@gmail.com. Mobile: +6282377277992.

Mid-International Conference in Public Health, Best Western Premiere Hotel, Solo, Indonesia, 18-19 April 2018 | 169 https://doi.org/10.26911/mid.icph.2018.03.05 